\title{
Kibera: The Biggest Slum in Africa?
}

\section{Amélie Desgroppes and Sophie Taupin}

\section{(2) OpenEdition}

\section{Journals}

Electronic version

URL: https://journals.openedition.org/eastafrica/521

DOI: $10.4000 /$ eastafrica. 521

ISSN: 2790-1076

\section{Publisher}

IFRA - Institut Français de Recherche en Afrique

\section{Printed version}

Date of publication: 1 September 2011

Number of pages: 23-33

ISSN: 2071-7245

\section{Electronic reference}

Amélie Desgroppes and Sophie Taupin, "Kibera: The Biggest Slum in Africa?", Les Cahiers d'Afrique de I'Est / The East African Review [Online], 44 | 2011, Online since 07 May 2019, connection on 09 December 2021. URL: http://journals.openedition.org/eastafrica/521 ; DOI: https://doi.org/10.4000/ eastafrica. 521

This text was automatically generated on 9 December 2021

Les Cahiers d'Afrique de l'Est / The East African Review 


\title{
Kibera: The Biggest Slum in Africa?
}

\author{
Amélie Desgroppes and Sophie Taupin
}

\section{Introduction}

1 Kibera, the infamous slum in Nairobi-Kenya's capital-, is viewed as "the biggest, largest and poorest slum in Africa." After the First World War, the British government allowed the Nubians to settle in a forest ${ }^{1}$ at the edge of Nairobi, as a reward for their service. However, after Kenya's independence, the government claimed this land as its own. Nubians continued to built and spread urbanization in Kibera, welcoming new comers from all over the country. Nowadays, Kibera is surrounded by the richest areas of Nairobi and it is also close to the industrial area. These two areas provide job opportunities that attract rural Kenyans.

Kibera's extraordinary figures have been legitimized by non-governmental organizations (NGOs), the media and politicians who usually quote the stunning figure of 700,000 to 1 million residents. Where did these figures come from? Are the superlatives used for Kibera justified? The only reliable source of information that has been used, with regard to Kibera's population, is a un-habitat/research international report (2005) giving a figure of between 400,000 and 700,000 Kiberans. Given that the surface area of Kibera is $2.38 \mathrm{~km}^{2}$, the density for 700,000 inhabitants would be about 300,000 inhabitants per square kilometre; that is more than Bangladesh's highest slum population density $\left(250,000\right.$ inhabitants per $\left.\mathrm{km}^{2}\right)$. Moreover, the 1999 census offers no adequate geographical division to properly count Kibera's population. For example, according to Carolina for Kibera, an important NGO in Kibera, "half of the population of Kibera is under the age of 15"; information that comes without a source.

Despite this elusive aspect of Kibera, figures on this slum's demographics are crucial for policy makers and developers. It is for this reason that the IFRA and Keyobs engaged in a survey that was aimed at acquiring better knowledge on Kibera residents. This project utilised a GIS based estimation of the population and a fieldwork household survey to collect demographic data. The results of the survey suggest that previous figures are a substantial overestimation of Kibera's population. In this paper, we will present the 
new figures obtained and the methodology employed in order to define the characteristics of the Kibera population.

\section{How Many People Live in Kibera?}

4 As the distribution of the buildings in Kibera is relatively uniform (Figure 1), GIS was considered a potentially relevant tool for the estimation of the population.

Figure 1: Satellite Image of Kibera

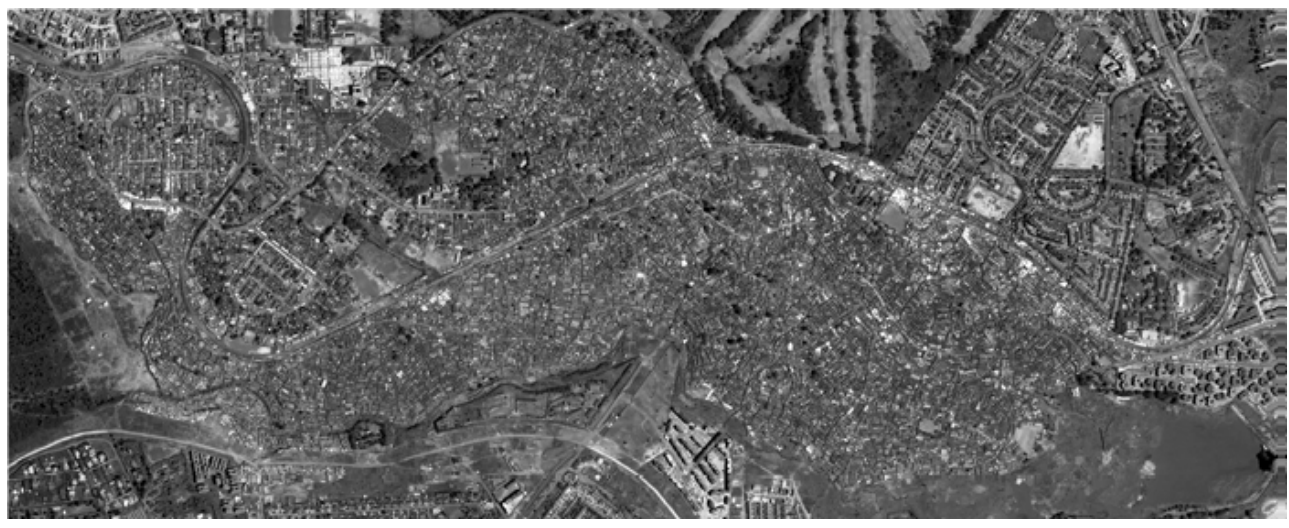

Source: Keyobs (2009).

5 We sought to count the population in selected buildings through random sampling in order to extrapolate the figures of the sample to the whole built area. On the one hand, Keyobs took the aerial satellite image of Kibera on 19 February, 2009 and designed the shapefiles $^{2}$ of the buildings, the roads and rivers. On the other hand, IFRA conducted the fieldwork and completed this information by identifying landmarks such as clinics, schools, churches, NGOs and government offices (Figure 2). In total, 17,045 buildings were counted and designed. In order to conduct the demographic survey, 500 structures (buildings), which represent $2.93 \%$ of the buildings, were selected at random. However, due to field limitations, the final sample was eventually 478 structures. 


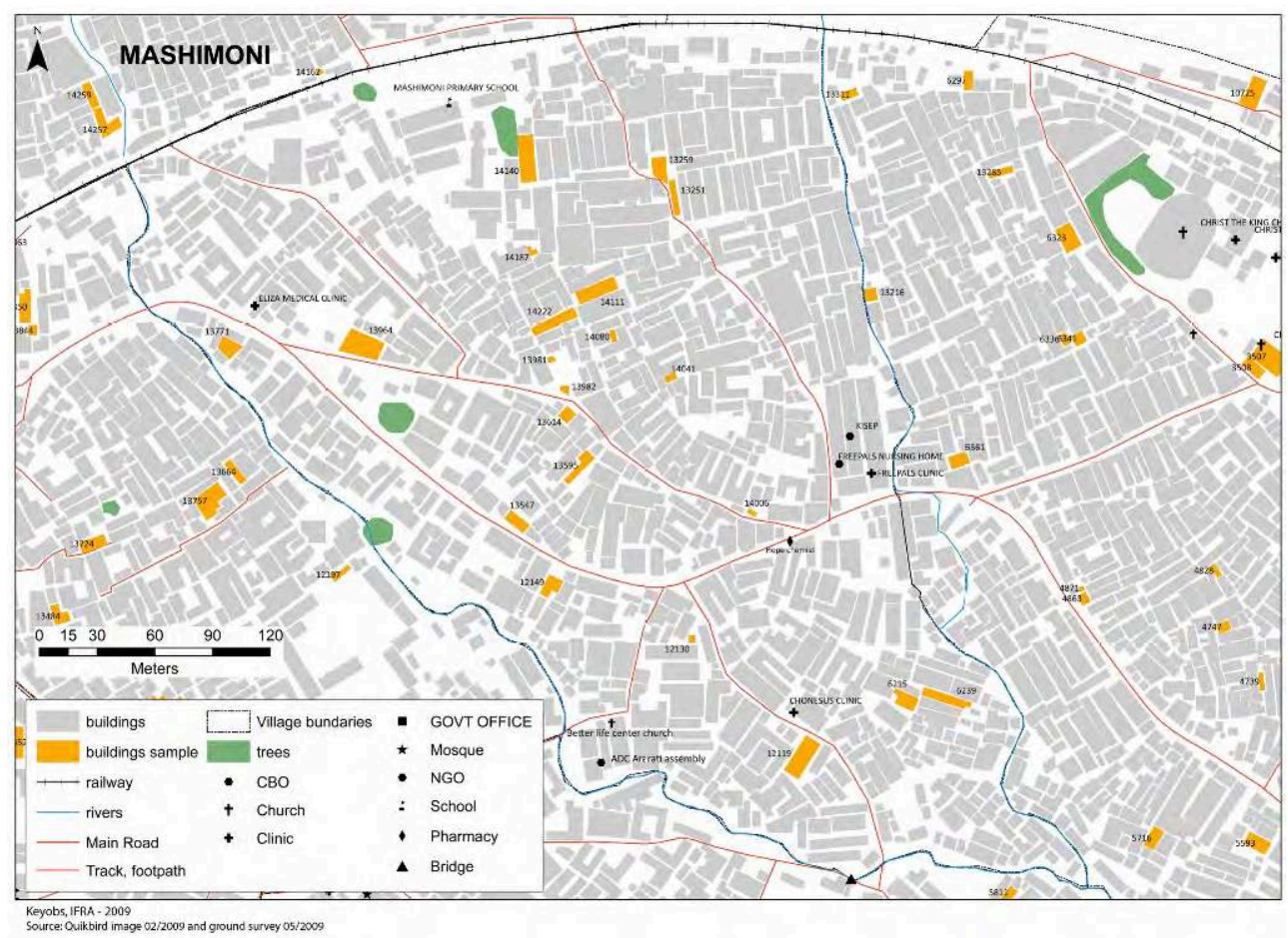

Source: Keyobs-IFRA (2009).

The field survey was conducted throughout Kibera by 12 surveyors from the community, coordinated by a supervisor. The surveyors were recruited from Kibera to make work easier and to legitimise the project. A one-day training was given to explain the scope, objectives and methodology of the ground survey.

Surveyors were gathered in teams of two, each team was given two administrative villages to survey; the sample buildings were marked in orange on the ground survey maps (figure 2). The harder part of the work was to find the right structure in the slum as some paths are closed or sewages/small rivers block the way. Some buildings were also found to be demolished or inexistent. Whenever a house was found closed on two occasions, the surveyors were to obtain the basic information from the neighbour(s) i.e. Number of people and their gender. Out of the 500 buildings sampled, 22 buildings were missing for several reasons: some were unreachable, others were found demolished; 5 of them were inexistent due to the lack of precision of the satellite image and in some houses, people refused to give information. In summary, our results cover 478 structures (buildings), 1,913 units (rooms/houses) and 5,359 residents of Kibera. Under one roof, the number of rooms range from $1-30$ and one room is generally occupied by one household. Out of the 1,913 units, 1,725 were residential and the others were businesses, latrines, churches or other types of structures.

The number of residents counted in the sample was extrapolated using two different methods (table 1):

The first method is based on the buildings' area where $+7 \%$ error was applied for all results, taking into consideration $3 \%$ of non response and error of digitalization. For the built surface area of the sample of 3.7 ha, there are 5,359 residents therefore for 130.3 ha of built area, the number of residents is 201,935 . 
10 The second method used is the extrapolation of the population by the number of buildings. For the 478 buildings sampled, there are 5,359 residents, therefore for 17,045, the estimated population is 204,473 (including $+7 \%$ error).

Table 1: Estimation of Kibera Population

\begin{tabular}{|l|l|l|l|l|}
\hline & $\begin{array}{l}\text { No. of } \\
\text { Structures }\end{array}$ & $\begin{array}{l}\text { Surface Area } \\
\text { (ha) }\end{array}$ & $\begin{array}{l}\text { Kibera } \\
\text { Population }\end{array}$ & $\begin{array}{l}\text { Final results (+7\% } \\
\text { error) }\end{array}$ \\
\hline Sample & 478 & 3.73 & 5,359 & \\
\hline Kibera & 17,045 & 131.8 & & \\
\hline Area (per structure) & & & 188,725 & (a)201,935 \\
\hline $\begin{array}{l}\text { Area (per no. of } \\
\text { structures) }\end{array}$ & & & 191,097 & (b)204,473 \\
\hline
\end{tabular}

Source: Field survey by Keyobs-IFRA (2009).

11 The results per village show a surprising heterogeneity throughout the different villages of Kibera. Kambi Muru and Laini Saba have a density of 48,000 inhabitants per $\mathrm{km}^{2}$ while Soweto West and Kianda are highly dense with 129,000 inhabitants per $\mathrm{km}^{2}$. Soweto West and Kianda have the highest rates of children, while Kambi Muru and Laini Saba have the highest rates of single and business people. The average density is around 87,500 inhabitants per $\mathrm{km}^{2}$ (figure 3).

12 Although our final result is far from the 1 million inhabitants, it is corroborated by other sources. UN-HABITAT did their estimation on the basis of a survey led by Research International in 2004. This survey found that the average household size was 5 persons and displayed an estimation of 400,000 to 700,000 people (Research International, 2005). Our survey has revealed that there is an average of 3.2 persons per households. 


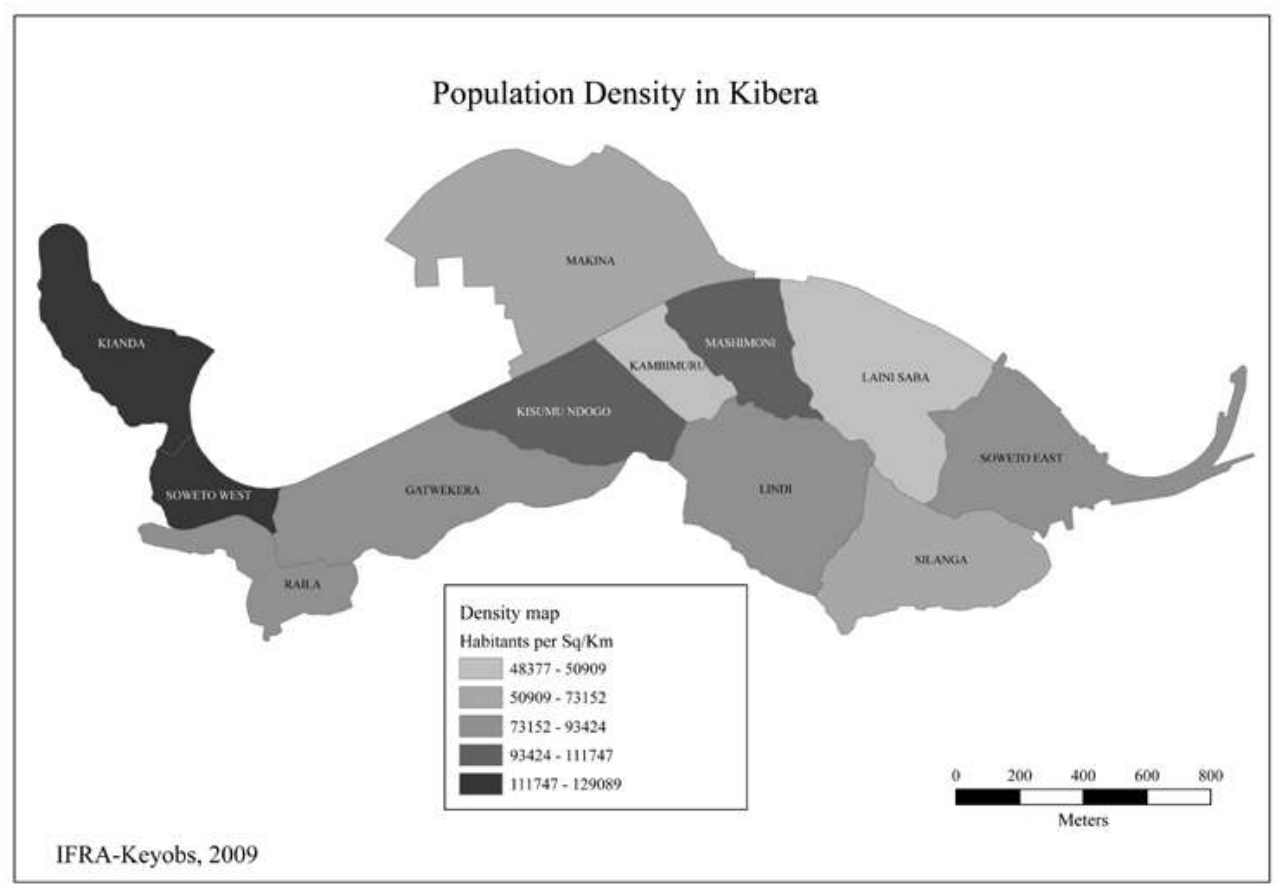

Source: IFRA-Keyobs Field Survey (2009).

In order to validate our final results, we compared them with other figures from different sources. Stephano Maurras (Map Kibera, 2008), an independent researcher, conducted a similar survey in May 2008, seeking for a credible figure of the Kibera population. He chose one village, (Kianda), for a door-to-door survey and extrapolated the number of dwellers to the whole of Kibera and his estimation of this population is 252,500 residents. If we base our calculation on the estimated figure of Kianda village, meaning an extrapolation of Kianda population, the estimation of the population is 271,319 inhabitants in Kibera. This method may give a higher result because Kianda was found to be one of the most densely populated villages (Figure 3). The Mapping Kibera Project survey corroborates the results of the Keyobs-IFRA survey as its findings are within the same range. Carolina for Kibera used approximately $90 \%$ of Gatwekera village in their longitudinal study; we added $10 \%$ to their results and found a very slight difference with ours (Table 2).

Table 2: Comparative Sources on Kibera Population

\begin{tabular}{|l|l|l|}
\hline Village Name & Other Sources' Population Estimation & IFRA Estimation \\
\hline Kibera & 252,500 (Map Kibera, 2008) & 204,473 \\
\hline Gatwekera & 24,402 (CFK) & 24,666 \\
\hline
\end{tabular}

Source: Carolina for Kibera (CFK) and Map Kibera, 2008.

The combination of GIS and a ground survey is relevant for an estimation of the population of an informal settlement, although this methodology has its limits. The satellite image has a resolution of $0.6 \mathrm{~m}$, which is not precise enough for the digitalization (design) of the buildings. While beginning the ground survey, we realized 
that the map was sometimes not accurate; trees hid houses, open spaces where designed as buildings and some buildings were not accurately shaped. Another challenge experienced in locating the right structure on the ground. The surveyors were sometimes tempted to choose a random structure when the one they were supposed to find was unreachable. Whenever the results were found inaccurate (a large structure with few people), investigations were repeated. Indeed, the figure of 205,000 dwellers in Kibera is much less than expected. Although a much higher figure was expected, the IFRA-Keyobs' results are corroborated by other sources.

\section{Who are the People Living in Kibera?}

Also a subject of fantasy, the inhabitants of this informal settlement are often described, in the NGO and media discourse, as young and jobless. On NGO websites, statistics are given without any supporting sources and they are often alarmist about the socio-economic status of Kibera's dwellers. As proven by the preceding field results, the average household consists of 3.2 persons which is lower than expected, going by research international's findings of an average of five people per household. These findings could be explained by the high rate of single persons in the eastern part of Kibera (figure 4), where the average household size is less than 3 people. The 2007-8 post-election violence (PEV) might have played a role. Laini saba is a village from which a lot of Kikuyus and Kambas ${ }^{3}$ fled during that period of violence; this might also explain the high rates of single persons.

Figure 4: Single Persons' Households

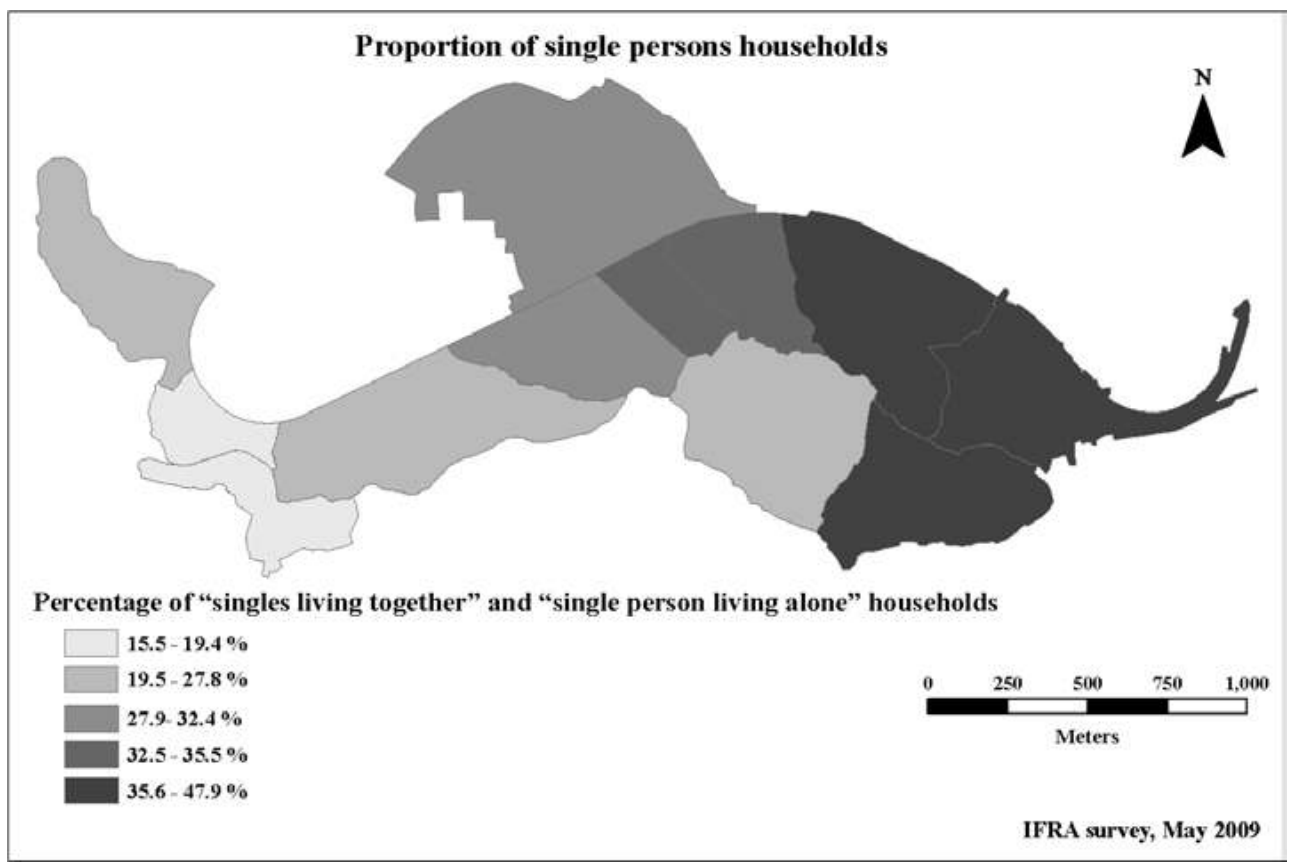

Source: IFRA-Keyobs Field Survey (2009).

The villages situated in the western part of Kibera have the highest household sizes: Kianda 3.5; Soweto West 4.5 and Raila 4.2 (persons per household). This area of Kibera is 
mostly composed of young couples from Western Province. The percentage of children (0-17 years) is around 50\%, while the average for Kibera is $36.5 \%$ (Figure 5).

Figure 5: Age Distribution

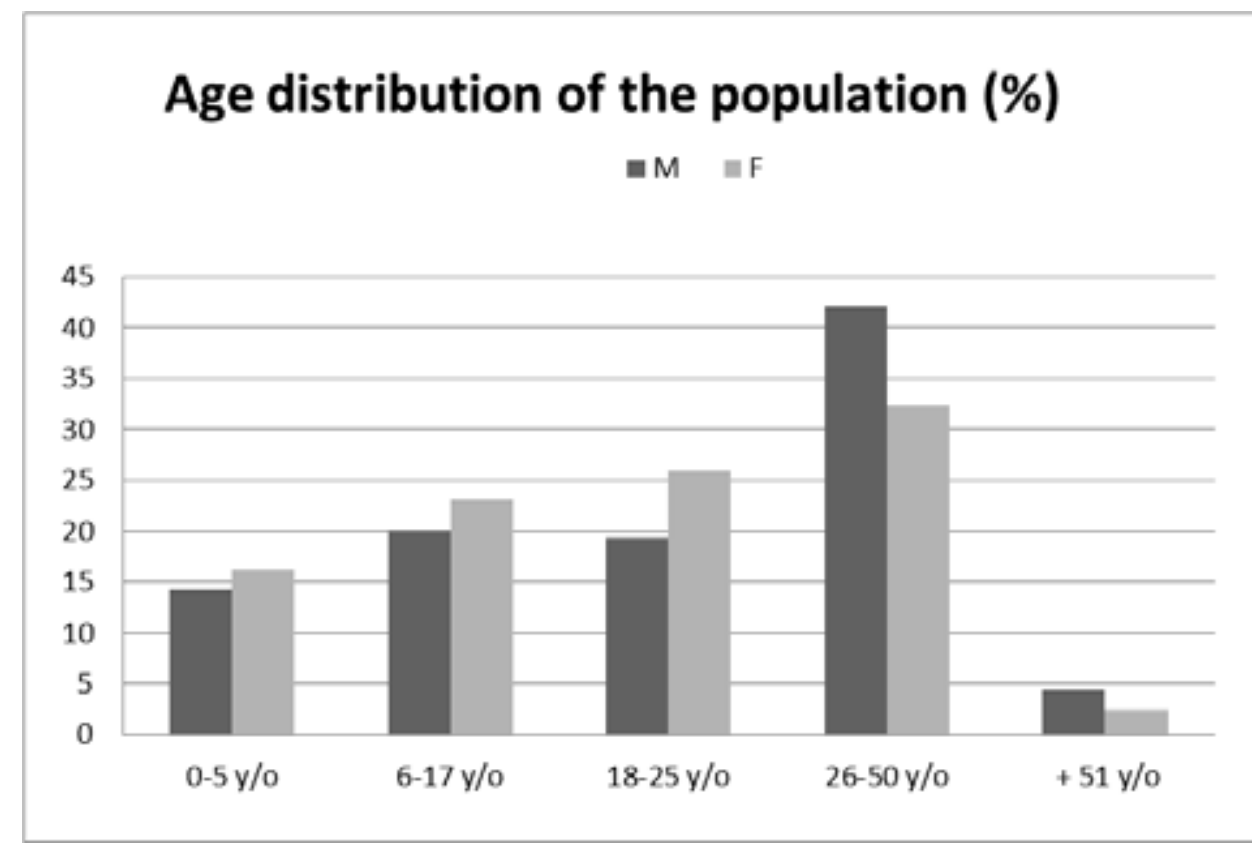

Source: IFRA-Keyobs Field Survey (2009).

Figure 6: Occupation

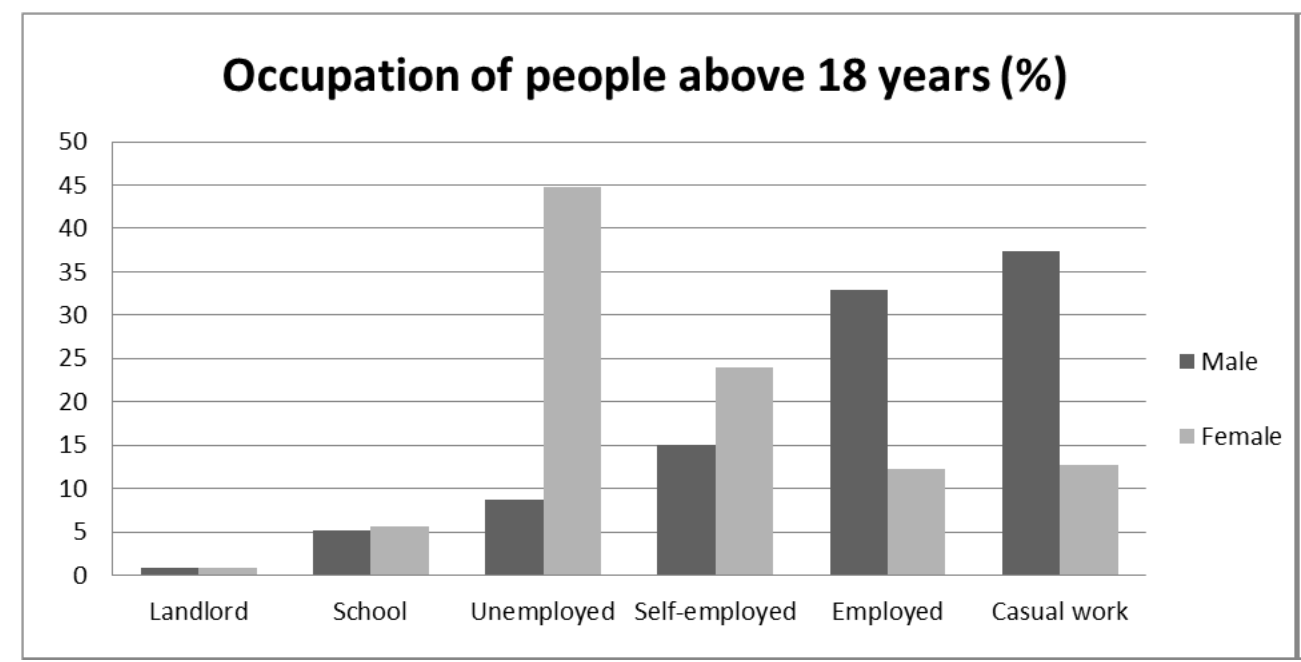

Source: IFRA-Keyobs Field Survey (2009).

In Kibera, only $8.5 \%$ of the men above 18 years stated they have no occupation (figure 6). Most of the residents' occupations are informal, meaning that a lot of jobs are not recorded in official employment statistics. If we look at the age distribution, there are more women than men, except between the ages of 26 and 50 years (figure 5). Therefore, it could be suggested that the male migration for work is quite common. The eastern part of Kibera is close to the industrial area and it has more than $40 \%$ of households composed of a single person or "singles living together" (figure 4). Soweto 
east and Silanga have the highest rates of employed men $^{4}, 79 \%$ and $76 \%$ respectively. It shows that a lot of men are coming to Nairobi to work; leaving their families in their rural areas. In Kibera, $10 \%$ of the households are comprised of singles sharing a room, a situation that helps reduce the cost of living in Nairobi, while $23 \%$ of the households are composed of a single person living alone. They are mostly young single and married men, working as guards, gardeners, construction or factory workers, who send money to their families.

Job insecurity is still a real problem: $45 \%$ of employed people are self-employed or those who get work on a day-day basis. Both activities do not guaranty a regular income so households are still vulnerable and poor. The main activity for women is self-employment (24\%) with activities such as selling vegetable or fish and cooking local food. The average income for women is $42 \%$ lower than the average man's. Indeed, women have to look after their young children, do the house work therefore, they have less time for working outside.

The income per person was calculated by dividing the income per household by the number of individuals; for Kibera it is 3,977 Kenyan shillings (KSh) per person per month (USD 39). In 2003, UN-HABITAT set the poverty level at KSh 2,645 per person per month (USD 26) in urban areas in Kenya. This poverty level could be higher in recent times due to inflation. With an average income of KSh 2,260 per person per month (USD 22), single women with kids are the most vulnerable people. Another vulnerable category is people living in a nuclear family where $68 \%$ live with less than KSh 2,645 per month. The singles seem to be less poor, but we can consider this as a bias as they usually share their income with their families living outside Nairobi. The map of the people living below the poverty line shows that the western part of Kibera, which has the highest rates of children, is also the poorest area (figure 7). 
Figure 7: People Living Below the Poverty Line

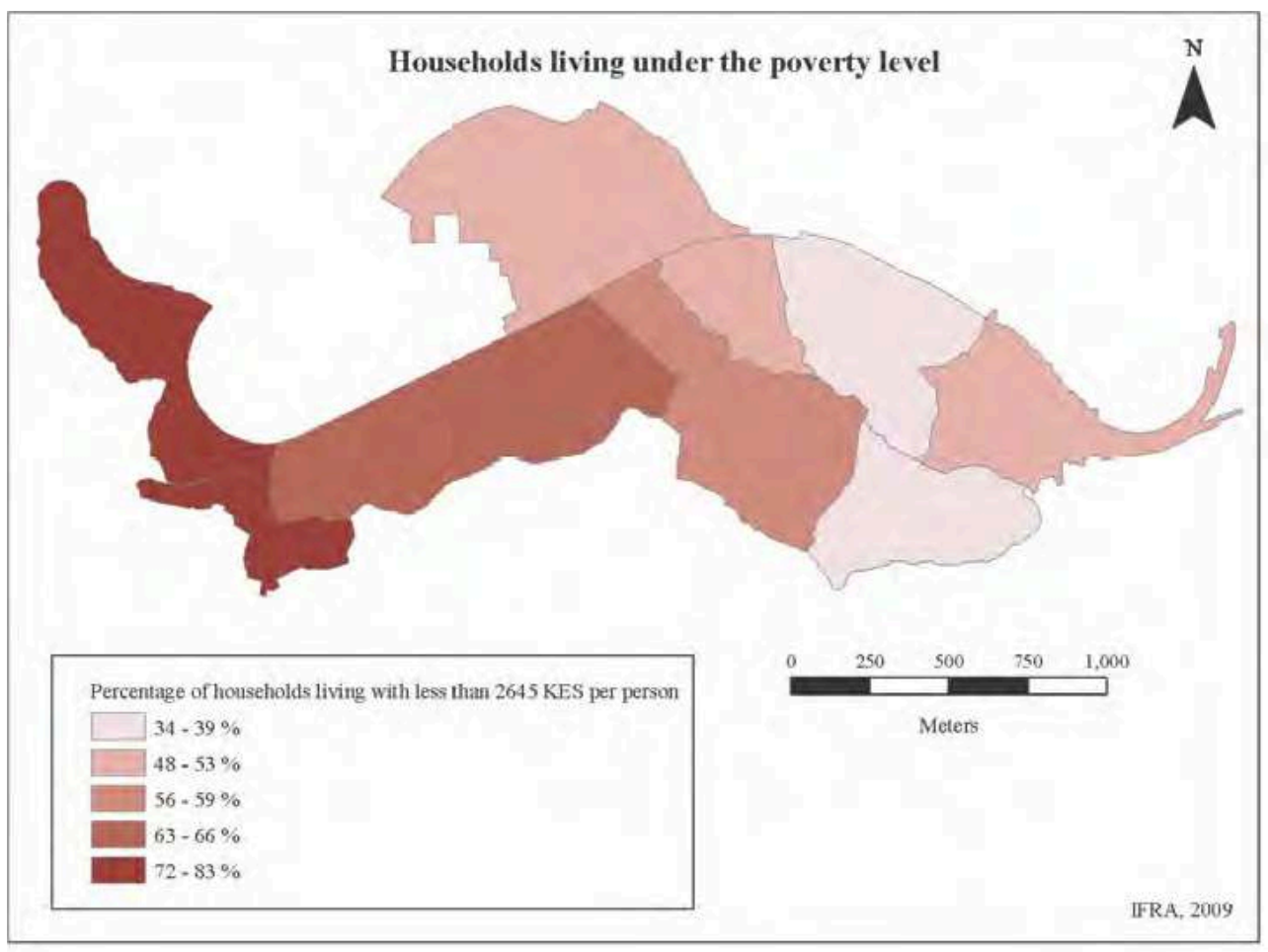

Source: IFRA-Keyobs Field Survey (2009)

\section{Conclusion}

The labelling of Kibera as "the biggest slum in Africa" has become a slogan but it is inappropriate to say that it is a reality. The results presented in this article showed that the population of Kibera is a lot less than expected. Kibera is certainly large in terms of surface area, but no study yet has been made to compare Africa's informal settlements. Our estimation confirmed the real situation, as 170,070 people were enumerated in Kibera during the 2009 census. Moreover, this survey provides an up-to-date estimation of the population and new statistics on poverty levels, employment and age of the population. The combination of remote sensing and ground survey is extremely relevant and must be pushed for in future demographic and population projects.

Nevertheless, the methodology has its limits. The satellite image has a resolution of $0.6 \mathrm{~m}$, which is really not adequate for the digitalization of slum buildings. Indeed, only the roofs of the buildings are detected and subtle limitations could not be detected from the satellite. Moreover there is no unique distinction between an individual housing structure and a building. Several buildings were also found to be housed under one roof. This remote-sensing methodology is a new and relevant tool, although improvements could be done such as acquiring a satellite image with a better resolution and investing in better training of surveyors. This study has shown that remote sensing and GIS technologies have an important role to play in population projects. 


\section{BIBLIOGRAPHY}

Amis, Philip. 1984. "Squatters or Tenants: The Commercialization of Unauthorized Housing in Nairobi.” World Development 12 (1): 87-96.

Maupeu, Hervé \& Jerôme Lafargue. 1998. "La société civile kényane : Entre résilience et résistance.” Politique Africaine 70: 61-73.

Map Kibera. 2008. http://mapkiberaproject.yolasite.com/maps-andstatistics.php

Mbataru, Patrick. 2004. "The Anatomy of a Crisis: Transitional Politics and the Rent Crisis in Nairobi." L'Afrique Orientale, Annuaire 2003: 189-232.

Research International. 2005. Kibera Social and Economic Mapping: Household Survey Data. Nairobi: Government of Kenya/UN-HABITAT.

Rodriguez-Torres, Deyssi. 1995. Nairobi: Le bidonville face à la ville. Cahiers du CIDEP 24. Paris: L'Harmattan.

Rodriguez-Torrès, Deyssi. 1998. "Entre informel et illégal. Survivre à Nairobi : Le Kenya. Le contrat social à l'abandon." Politique Africaine 70: 54-60.

Stergou, Charlotte. 2009. La Construction territoriale : Stratégies d'acteurs et enjeux pour la mobilisation citoyenne, zone informelle de Kibera, Nairobi. Mémoire de recherche sous la direction de Gérard Salem, Université Paris 10 Nanterre.

\section{NOTES}

1. Kibra means "forest" in the Nubian language.

2. A shapefile is a geographical geo-referenced information file in Arcview, software used in Geographical Information Systems (GIS).

3. Kikuyus and Kambas are two different ethnic groups in Kenya.

4. Men above 18 years employed on a monthly or daily basis.

\section{ABSTRACTS}

This article presents the findings of the estimated population of Kibera, often said to be the "biggest slum in Africa." This estimation was done in 2009 by the French Institute for Research in Africa (IFRA) in Nairobi and Keyobs, a Belgian company, using Geographical Information Systems (GIS) methodology and a ground survey. The results showed that there are 200,000 residents, instead of the 700,000 to 1 million figures which are often quoted. The 2009 census and statistics on Kibera's population also confirmed that the those findings were accurate. 
INDEX

Geographical index: Kenya

\section{AUTHORS}

\section{AMÉLIE DESGROPPES}

Cartographer and Project Manager at the French Institute for Research in Africa (IFRA) Nairobi, Kenya.

SOPHIE TAUPIN

Sophie Taupin, GIS expert, Project Manager at Keyobs, Brussels, Belgium. 